\title{
A Study of the Factors Related to Cardiopulmonary Resuscitation Physical Fatigue and the Quality of Resuscitation
}

\author{
Mojtaba Rad, Mostafa Rad \\ ${ }^{1}$ Faculty member of Nursing and Midwifery, Sabzevar University of Medical Sciences, Sabzevar, Iran \\ ${ }^{2}$ School of Nursing and Midwifery, Sabzevar University of Medical Sciences, Sabzevar, Iran
}

SUMMARY

Effective chest compression is an important factor playing a key role in the cardiac arrest patient survival. An understanding of the factors causing an early physical fatigue can help to improve the quality of CPR operations in hospitals. Therefore, this study aimed to assess the factors relevant to the onset time of physical fatigue and resuscitation quality during cardiopulmonary resuscitation (CPR) provision by Iranian nurses.

The present cross-sectional study was performed on 194 subjects selected based on a stratified random sampling procedure from different hospital wards. The participants were required to perform CPR operations on a manikin. As they were performing CPR, the time and the quality of compressions were measured by a chronometer and visual analogue fatigue scale, respectively. The rescuers themselves reported the onset time of physical fatigue.

Statistical analyses run on the collected data revealed that the majority of participants experienced extreme physical fatigue after a two-minute CPR operation. Moreover, about $71.2 \%$ of the participants managed to provide compressions over five centimeters deep. Finally, the physical fatigue experienced by the participants was meaningfully correlated with the body weight, sex, university degree, and work place of the participants $(p<0.05)$.Since the findings of the present study showed that various factors including the sex, weight, height, university degree, and the work place of the rescuer were significantly correlated with the onset time of physical fatigue experienced during CPR operation, it is recommended that male nurses with greater height and weight be employed in the rescue teams in ICU wards. Moreover, it seems mandatory for the nurses currently working in such teams in hospitals to improve their physical fitness through doing aerobics on a regular basis so that they may experience less fatigue during their CPR operations in future.

Key words: physical fatigue, CPR, quality, nurses, efficiency 


\section{INTRODUCTION}

Cardiopulmonary resuscitation (CPR) refers to a set of coordinated measures taken in order to restore the vital functioning of the two important organs of the heart and lung. The main purpose of CPR is to restore a partial flow of oxygenated blood and breathing until the spontaneous circulation of blood returns in the patient (1). It is of paramount importance to keep in mind that the most vulnerable organ to ischemia is the heart itself, so measures need to be taken to restore enough blood circulation immediately in the coronary arteries in order to save the heart. This can be achieved through first performing chest compressions and later through special medications and techniques so that the heart maintains its normal functioning (2). In CPR, performing external high-quality chest compressions is of great importance in that it can increase blood output of the heart, increasing the blood flow to the heart and the brain, and hence improving the survival chance of the patient in the short run (3). The results of the studies done so far on CPR teams in hospitals shows that the chest compressions are not deep enough and that there are interruptions in compressions and ventilations due to the fatigue of the CPR team members (4). The results obtained so far indicate that, on average, only 10 to 15 percent of the patients receiving CPR in hospitals survive. However, this rate varies in different countries. Therefore, it seems essential to study the factors causing this lack of success in CPR operation so that better approaches and methods can be developed to efficiently control the potential risks and threats in future (5). The results of many studies indicate that the physical fatigue of the rescuers occurs during the first minute after the start of CPR operation (6). Moreover, the rescuer is unaware of the effect of his/her physical fatigue on the decline of the quality of his/her compressions (7). Inadequate chest compressions can be due to the physical fatigue of the rescuer, a factor which leads to the lowering of the blood flow to vital organs. Moreover, the incomplete return of the chest after every compression leads to increased internal chest pressure, and has some adverse hemodynamic effects including a reduction of blood flow in the coronary arteries and myocardial wall and decreased perfusion of the brain $(4,8)$. The ideal objective for a CPR operation is 100 percent survival chance. However, there are many potential factors which reduce the survival chance such as the background diseases of the patient, the time lapse between the heart arrest and the start of CPR operation, the availability of skillful and experienced CPR personnel, and access to necessary medical devices and instruments for CPR operation (9). Over the last few decades, many studies have been designed and performed to measure the physical fatigue of the CPR rescuers. However, these studies have come up with incompatible results (10). Rieraet al. studied the physiological effects of performing CPR on rescuers for two minutes of giving CPR to patients incessantly. The results showed that the rescuers could give CPR to patients for two minutes without interruptions (11). However, in their study, Ashton et al. showed that the depth of chest compressions decreases after the first minute, and that the complaints of the rescuers for physical fatigue increased from the third and the fourth minutes (12). However, in one study, it was shown that the CPR operation could continue for about 10 minutes without any interruptions (10). As mentioned so far, the onset of physical fatigue has been reported to vary between one to ten minutes after the initiation of the CPR operation, all of which belong to other countries (13). In their study, Hasegawa et al. showed that the weight of the rescuer and the success of CPR are closely related such that the heavier the rescuer was, the lower was the physical fatigue duration CPR operation (3). Studies done show that there are significant differences between Iran and other countries in terms of a plethora of variables including the physique of nurses, and also in terms of other important factors affecting survival chance such as motivation, and survival expectation among CPR personnel. Moreover, because of a shortage of experienced medical personnel, nurses have to work for too many shifts during the week and for longer hours compared to nurses in other countries. In addition, in Iran, there is no balance between the number of male and female nurses (in that female nurses outnumber the male ones) especially in emergency wards where the frequency of CPR operations performed is higher than any other ward in hospitals $(14,15)$. Hence, it seems quite natural to investigate the resuscitation potential and the quality and number of chest compressions given by CPR personnel in Iranian hospitals. Considering the fact that cardiac arrest is one the most important medical emergencies taking place unpredictably in different situations, and also the fact that the rate of successful CPR operations is an important index for good hospitals, this study was designed to deal with the factors relevant in physical fatigue due to CPR operation, and the effect of this fatigue on the quality of CPR operations provided by Iranian nurses. 


\section{METHOD}

The present cross-sectional study was performed on 194 medical personnel in different hospitals in Sabzevar during 2015 to 2016. A stratified random sampling was used to select the participants from among the potential population. After the number of the female and male staff working in each ward was determined, the final participants for the inclusion in the sample were selected using a table of random numbers. Then formal invitations were sent to all selected subjects. The subjects were included in the final sample based on the inclusion criteria set for the study: holding a bachelor or master degree, having no physical disability, being well-informed of the correct way to perform a CPR operation, and showing consent to participate in the study.

Having been informed about the method and the purpose of the study, the participants filled out and signed the written consent forms. In the next stage, the demographic information about the participants was collected and recorded. After completing the relevant demographic forms, all participants were invited to go into the resuscitation room to perform CPR on manikin already prepared for them by the researcher. Then, the participants started the CPR operation on a manikin placed on a bed in the resuscitation room. A chronometer was used to measure the time. As soon as the first compression was given on the chest of the manikin, the rate, depth, and quality of compressions and also the onset time of physical fatigue for all participants were measured objectively. For each participant, this objective measurement continued until he or she felt fatigued. The time and intensity of physical fatigue were measure on a self-report basis. During the CPR operation, the researcher checked the compression depth, turning on the error LEDs on the manikin. He also recorded the time of CPR operation for each participant. All the CPR operations given to the manikin by the participants were filmed so that a second rater could make his own objective measurements for comparison purposes in order that any possible errors related to the subjectivity of the measurements could be eliminated from the data. As stated, participant were asked to rate their physical fatigue using a visual analogue fatigue scale (VAFS). According to VAFS, a score of 1-3 shows the lowest amount of physical fatigue, a score of 4-7 was a mode- rate physical fatigue, while a score of 8-10 shows the highest degree of physical fatigue (16). The instrument showed a reliability of 0.85 . A content validity of 0.90 was estimated for the instrument by a team of experts consisting of some ten university teachers, two anesthesiologist and three hospital staff with more than ten years of work experience. The data were collected through demographic questionnaires and check-lists for the number, depth and intensity of compressions, onset time of physical fatigue during the CPR, and the intensity of fatigue after ending CPR. Data were analyzed by SPSS (version 11.5). The statistical analyses done on data included descriptive statistics (frequency, mean, and standard deviation), and also the following inferential statistic analyses via chi-square test. All statistical analyses were performed with a significance level of $5 \%$.

\section{RESULTS}

In the present study, a sample of 194 male and female subjects met the inclusion criteria and participated in the project. There were $42.3 \%$ and $57.7 \%$ of male and female subjects, respectively. Eighty-four point five percent of the subjects hold a Bachelor Degree, while the remaining $15.5 \%$ of the subjects had a Master Degree. As to the employment, $19.6 \%$ of the subjects hold a full time job at the hospitals, with $37.1 \%$ and 43.3 $\%$ of them working in hospitals on a contractual and conventional basis, respectively. Seventy-seven point three percent of the subjects were married. With regard to the weight, $62.9 \%$ of them weighed between 50 and 70 kilograms. Moreover, $71.1 \%$ had a work experience between 1 to 10 years. Finally, some 69.1\% of participants were between 150 to 170 centimeters tall (Table 1). As to the depth of compressions, 138 subjects $(77.1 \%)$ managed to give compressions of more than 5 centimeters deep during their CPR, while 56 subjects $(28.8 \%)$ could not give 5 centimeters deep compression at all. Considering the frequency of compressions, some 144 subjects (73.6 \%) managed to give 51-150 compressions during their CPR operations to the manikin, with 80 subjects (41\%) rating their physical fatigue severity between 7-10 which showed moderate to extreme physical fatigue due to resuscitation. Moreover, $92.8 \%$ of the subjects had either no interruptions or interruptions less than 10 seconds during their CPR provisions. 
Table 1: The frequency of subjects participating in CPR operation based on demographic data

\begin{tabular}{|c|c|c|}
\hline & \multicolumn{2}{|c|}{ Study population demographics ( $N=194$ subjects) } \\
\hline Age & Age (years) Mean \pm S.D & $31.3 \pm 6.6$ \\
\hline \multirow{2}{*}{ Gender } & Male $N(\%)$ & $82(42.3)$ \\
\hline & Female $N(\%)$ & $112(57.7)$ \\
\hline \multirow{2}{*}{ Education } & ${ }^{* *} \mathrm{BSc} N(\%)$ & $164(84.5)$ \\
\hline & ${ }^{* * *} \mathrm{MSc} N(\%)$ & $30(15.5)$ \\
\hline \multirow{2}{*}{ Marital status } & Married $N(\%)$ & $150(77.3)$ \\
\hline & Single $N(\mathbf{o})$ & $44(22.7)$ \\
\hline \multirow{5}{*}{ Clinical experience (years) } & $1-5$ years $N(\%)$ & $80(41.2)$ \\
\hline & 6-10 years $N(\%)$ & $58(29.9)$ \\
\hline & $11-15$ years $N(\%)$ & $30(15.5)$ \\
\hline & $14-20$ years $N(\%)$ & $16(8.2)$ \\
\hline & Over 21 years $N(\%)$ & $10(5.2)$ \\
\hline \multirow{6}{*}{ Weight } & $40-50 \mathrm{~kg} \mathrm{~N}(\mathbf{\%})$ & $8(4.1)$ \\
\hline & $51-60 \mathrm{~kg} N(\mathbf{\%})$ & $56(28.9)$ \\
\hline & $61-70 \mathrm{~kg} N(\mathbf{\%})$ & $66(34)$ \\
\hline & $71-80 \mathrm{~kg} N(\mathbf{\%})$ & $32(16.5)$ \\
\hline & $81-90 \mathrm{~kg} N(\mathbf{\%})$ & $22(11.3)$ \\
\hline & $91-100 \mathrm{~kg} \mathrm{~N} \mathrm{( \% )}$ & $10(5.2)$ \\
\hline \multirow{4}{*}{ Height } & $150-160 \mathrm{~cm} \mathrm{~N}(\%)$ & $64(33)$ \\
\hline & $161-170 \mathrm{~cm} \mathrm{~N}(\%)$ & $70(36.1)$ \\
\hline & $171-180 \mathrm{~cm} \mathrm{~N} \mathrm{( \% )}$ & $48(24.7)$ \\
\hline & Over181cm N (\%) & $12(6.2)$ \\
\hline
\end{tabular}

${ }^{*}$ Number (Percent), ${ }^{* *}$ Bachelor of Science, ${ }^{* * *}$ Master of Science

The results of the chi-square test did not show a statistically significant relationship between the age of the subjects and the number of the compressions. Seventy-two subjects who were below 30 years old and 76 subject with an age above 30 managed to give below 200 compressions to the manikin in the present study $(\mathrm{p}=0.643)$.

Chi-square test showed a statistically meaningful relationship between the sex of the subjects and the number and quality of given compressions $(p=0.000)$. More specifically, 40 male subjects (20\%) managed to provide more than 200 compressions incessantly without getting fatigued, while only 6 female subjects $(0.03 \%)$ managed to have a similar performance during their CPR operations. Moreover, 32 subjects (16.4\%) with weights above 70 kilograms gave over 200 compressions during their CPR operations without getting fatigued. However, those who were below 70 kilograms (84\%) could not reach 200 compressions in their CPR operations. Once again, there was a statistically significant relationship between weight and subjects ability to provide compressions without fatigue ( $\mathrm{p}=$ 0.001).
Similarly, the results obtained showed that there was a significant relationship between subjects' university degrees and their physical fatigue in that 134 subjects with Bachelor degrees (68\%) provided below 200 compressions, while only 16 Master subjects $(0.08 \%)$ had compressions fewer than $200(\mathrm{p}=0.001)$.

In a similar manner, the results obtained through the chi-square test on subjects' height and the number of compression revealed a meaningful relationship between these two variables $(p=0.001)$. While only 10 subjects out of a total number of subjects who were below 170 centimeters tall gave more than 200 compressions, about 42 subjects out of 134 subjects above 170 centimeters height managed to provide more than 200 compressions during their CPR operations.

However, the results of the chi-square test revealed no meaningful relationship between subjects' clinical work experience and the number of compressions ( $p=0.283)$.

As to the intensity of physical fatigue, more than 80 subjects (41\%) reported extreme physical fatigue within 2 minutes after the start of CPR operation (Table 2). 
Table 2: The correlation between effective massage rate and demographic data

\begin{tabular}{|c|c|c|c|c|}
\hline \multicolumn{2}{|c|}{ Total massage rate } & \multirow{2}{*}{$1-200$} & \multirow{2}{*}{$>200$} & \multirow{2}{*}{${ }^{*} \mathbf{P}$ value } \\
\hline \multicolumn{2}{|c|}{ Variable } & & & \\
\hline \multirow{6}{*}{ Age (years) } & $20-25$ & 36 & 8 & \multirow{6}{*}{$\begin{array}{c}{ }^{*} \mathrm{X}^{2}=3.373 \\
{ }^{* * *} \mathrm{Df}=5 \\
\mathrm{P}=0.643\end{array}$} \\
\hline & $26-30$ & 36 & 14 & \\
\hline & $31-35$ & 30 & 10 & \\
\hline & $36-40$ & 30 & 10 & \\
\hline & $41-45$ & 10 & 4 & \\
\hline & $46-50$ & 6 & 0 & \\
\hline \multirow[b]{2}{*}{ Gender } & Male & 40 & 42 & \multirow{2}{*}{$\begin{array}{c}\mathrm{X}^{2}=77.064 \\
\mathrm{Df}=5 \\
\mathrm{P}=0.00\end{array}$} \\
\hline & Female & 6 & 106 & \\
\hline \multirow{6}{*}{ Weight (kg) } & $40-50$ & 0 & 8 & \multirow{6}{*}{$\begin{array}{c}\mathrm{X}^{2}=45.346 \\
\mathrm{Df}=5 \\
\mathrm{P}=0.001\end{array}$} \\
\hline & $51-60$ & 4 & 52 & \\
\hline & $61-70$ & 10 & 56 & \\
\hline & $71-80$ & 16 & 16 & \\
\hline & $81-90$ & 14 & 8 & \\
\hline & $91-100$ & 2 & 8 & \\
\hline \multirow{2}{*}{ Education } & $\mathrm{BSc}$ & 132 & 32 & \multirow{2}{*}{$\begin{array}{c}\mathrm{X}^{2}=10.33 \\
\mathrm{Df}=1 \\
\mathrm{P}=0.001\end{array}$} \\
\hline & MSc & 16 & 14 & \\
\hline \multirow{5}{*}{ Work department } & Surgical & 45 & 5 & \multirow{5}{*}{$\begin{array}{c}X^{2}=8.44 \\
D f=4 \\
P=0.001\end{array}$} \\
\hline & Medical & 65 & 11 & \\
\hline & Emergeny & 16 & 14 & \\
\hline & $\begin{array}{c}\text { Critical } \\
\text { care }\end{array}$ & 15 & 12 & \\
\hline & Pediatric & 20 & 4 & \\
\hline \multirow{2}{*}{ Clinical experience (years) } & $1-15$ & 42 & 126 & \multirow{2}{*}{$\begin{array}{c}X^{2}=16.291 \\
D f=4 \\
P=0.283\end{array}$} \\
\hline & $16-20$ & 4 & 22 & \\
\hline \multirow{2}{*}{ Marital Status } & Married & 34 & 116 & \multirow{2}{*}{$\begin{array}{c}\mathrm{X}^{2}=0.399 \\
\mathrm{Df}=1 \\
\mathrm{P}=0.528\end{array}$} \\
\hline & Single & 12 & 32 & \\
\hline
\end{tabular}

${ }^{*} \mathrm{P}<0.05$ as significant, ${ }^{* *} \mathrm{X}^{2}$ : Chi-square test, ${ }^{* * *} \mathrm{Df}$ : Degree of freedom

Statistical tests showed no meaningful relationship between mean age, clinical experience, educational and marital status in both male and female.
However, there were significant difference between males and females in terms of participants' weight and height $(\mathrm{p}<0.05)$ (Table 3$)$. 
Table 3: Comparisons of mean age, weight, height, work experience, education,and marital status between men and women

\begin{tabular}{|c|c|c|c|c|c|}
\hline Group & Men & & Women & & *P Value \\
\hline Variable & Mean \pm S.E & Number & Mean \pm S.E. & Number & \\
\hline Age (years) & $32.9 \pm 6.8$ & 82 & $32 \pm 5.8$ & 112 & $\begin{array}{c}* * t=2.25 \\
P=0.29\end{array}$ \\
\hline Weight kg) & $77.1 \pm 10.9$ & 82 & $62 \pm 8.2$ & 112 & $\begin{array}{c}\mathrm{T}=11.08 \\
\mathrm{P}=0 / 0001\end{array}$ \\
\hline Height & $174 \pm 6.8$ & 82 & $161 \pm 5.4$ & 112 & $\begin{array}{c}\mathrm{T}=15.27 \\
\mathrm{P}=0 / 0001\end{array}$ \\
\hline $\begin{array}{l}\text { Clinical experience } \\
\text { (years) }\end{array}$ & $9.4 \pm 7.37$ & 82 & $9 \pm 8.2$ & 112 & $\begin{array}{c}t=2.8 \\
P=0.058\end{array}$ \\
\hline \multirow[b]{2}{*}{ Education } & ${ }^{* * * * B S N}$ & 68 & BSN & 96 & \multirow{2}{*}{$\begin{array}{c}{ }^{* * *} X^{2}=30 \\
P=0.076 \\
D f=1\end{array}$} \\
\hline & ${ }^{* * * * *} \mathrm{MSN}$ & 14 & MSN & 16 & \\
\hline \multirow[b]{2}{*}{ Marital status } & Married & 68 & Married & 82 & \multirow{2}{*}{$\begin{array}{c}X^{2}=25.67 \\
P=0.11 \\
D f=1\end{array}$} \\
\hline & Single & 14 & Single & 30 & \\
\hline
\end{tabular}

${ }^{*} \mathrm{P}<0.05$ as significant, ${ }^{* *}$ Data were analyzed with an independent sample $t$-test, ${ }^{* * *}$ Data were analyzed with the chi square test, ${ }^{* * *}$

Bachelor of Science in nursing, ${ }^{* * * *}$ Master of Science in nursing

\section{DISCUSSION}

An attempt was made in this study to deal with fatigue-inducing factors related to CPR operation, and the quality of resuscitation provided by Iranian nurses. The results obtained in this study suggested that there is a statistically meaningful relationship between sex, weight, height, and the university degree of the subjects on the one hand and the physical fatigue experienced during CPR provision on the other. Moreover, it was observed that, on average, the majority of the Iranian nurses experience extreme physical fatigue within two minutes after the start of the CPR operation.

The results indicated that there is a significant relationship between the sex of the subjects and the number of performed compressions. The results also showed that the majority of female nurses perform fewer effective compressions than their male counterparts manage to do. The results of the present study are in line with those obtained in the study done by Russo (17). In his study, the rate of compressions provided by female subjects was faster but they were less strong compared to those provided by male subjects. Therefore, in both studies, the compressions performed by female subjects were similar in terms of depth and quality. It seems that the majority of female nurses are unable to provide effective compressions in that they experience physical fatigue because they are shorter in height, lighter in weight, and less strong in physique compared to the male nurses. The difference observed in this study in the rate of compression provision between male and female subjects may be attributed to the fact that Iranian female nurses are physically less fit.

Moreover, the results obtained in this study showed that there was a meaningful relationship between the participants' body weight on the one hand and the number of effective compressions and the physical fatigue felt during resuscitation on the other. In this regard, the findings of this study are compatible with those observed in the study by Hasegawa et al (3). According to the present results, the majority of participants in this study weighed less than 70 kilograms and provided the fewest number of effective compressions during their CPR operations. Therefore, 
the lighter the subjects, the less deep will be their compressions, and the sooner they will feel fatigued during resuscitation. In a similar vein, Hasegawa et al. observed that the compressions given to the manikin by light-group subjects were neither strong nor deep enough (3).

Our findings showed that there was a significant relationship between the subjects' height and the onset time of physical fatigue, which is in agreement with the results observed by Russo et al. They showed that as weight and physical fitness increased, the subjects experienced less physical fatigue during CPR. Similar results were observed in the study done by Krikscionaitiene et al. They showed that the amount of the pressure exerted by subjects with a comparatively lighter weight was considerably low (18). It can be concluded that as weight decreases, subjects get fatigued sooner, with the quality of resuscitation decreasing accordingly. In the present study, the majority of the subjects felt fatigued rather soon during CPR provision, a result which is due to the fact that the majority of subjects included in the sample of the study were female nurses with a rather low body weight. In another study, participants with a higher BMI, and a good index of physical fitness, felt less fatigued during CPR operation (17). As we know, there is a natural relationship between one's height and weight so that as one increases, the other one goes up, too. Moreover, height allows the rescuer to position his arms at a 90degree angle relative to the plane of the chest of the patient so that they can give more effective compressions without getting fatigued. The results of this study also revealed that the hospital ward the subjects were working at was an another important factor correlating with the provision of effective compressions with lower fatigue. Based on the findings of this study, the nurses working at critical care unit reported lower fatigue during CPR operation. As there are no other studies coming up with similar results in this regard, it can be inferred that the nurses working in critical care unit experience more cases of CPR during their work time, and therefore, feel the need for CPR skills more compared to other nurses. Moreover, these nurses seem to be highly motivated to save the lives of patients. Thus, they are more likely to spend more time developing CPR skills, and to get physically prepared to provide life-saving CPR services to patients once the need emerges (19).

The university degree the participants held was another important factor influencing compression quality and fatigue onset time. In the present study, the participants holding a Master degree reported lower fatigue level compared to those holding a Bachelor degree. Although the participants with a Bachelor degree outnumbered those with a Master degree, the results of the statistical analyses revealed a meaningful difference between these two groups of nurses in terms of fatigue onset time. It seems that significant difference is due to the fact that those with Master degrees are familiar with the correct form of CPR techniques, and probably position their arm and shoulders in a correct form while giving compressions to the patient (19).

As to the quality of resuscitation, the majority of the participants in the present study managed to give sufficiently deep compressions on the manikin. According to the CPR Protocol released by the American Heart Association (2015), the compressions given should be between 5 to 6 centimeters deep (20). However, the participants of the present study felt fatigued within 2 minutes after the start of CPR. Once they got fatigued, the quality of their compressions decreased drastically in terms of depth and rate, a finding which is in line with the findings observed by Heidenreich et al. In their study, they observed that the pressure given to the rib cage of the manikin during the first minute was greater than that given in the subsequent minutes $(11,6)$. In the present study, the compressions given to the manikin during the first minute were appropriate, with a depth of 5 centimeters. However, as the time passed and the participants entered the second minute of the CPR operation, the compressions given deteriorated in rate and depth. The early physical fatigue experienced by the majority of the subjects in the present study might be related to the fact that most of them were not physically fit, and that they did not use the muscles of the upper part of their body by not positioning their arms in a vertical position perpendicular to the chest of the manikin.

\section{Limitations of the study}

The present study investigated the quality of compressions given to a manikin and not human samples. Moreover, the subjects of the present study provided compressions in a stress-free environment which is by no means comparable to the stressful conditions faced in hospitals on a daily basis. In addition, the present study focused on CPR quality of compressions and physical fatigue just through considering the quality of compressions, without taking into account ventilation. Although measuring the pressure quality is a good standard to evaluate compressions and to study physical fatigue during CPR operation, it is not until one can perform CPR operation on human cases in real situations that one can come 
close to measuring the real physical fatigue of CPR personnel, and the quality of their CPR operation. Last but not least, all the participants in this study were well aware of the purpose of the study, and knew that they were supposed to use all their strength in giving CPR and to spread their energy during CPR so that they might get fatigued rather late in their CPR operation. Some subjects may not have taken the whole project seriously, and may not have done their best.

\section{CONCLUSIONS}

Physical fatigue had an adverse effect on the quality of compressions on the rib cage and compression depth during the first and the second minutes of the CPR operation. Moreover, on average, Iranian nurses reported sooner and more extreme physical fatigue than nurses from any other country studied so far. Various demographic variables such as sex, height, education, hospital ward in which one works can be correlated with physical fatigue, and therefore can interfere considerably with the quality and effectiveness of resuscitation. As revealed by the results of this study, compared to female subjects, the male ones managed to give compressions for longer period of time without getting fatigued and reported fatigue later. In addition, those with greater height and weight can provide more effective CPR compressions, experiencing less physical fatigue. Based on the findings of the present study, those working in ICU wards should be physically fit so that they may experience fatigue while giving CPR compressions. Considering the fact that currently the majority of the nurses working in hospitals are females, it is seems advisable for authorities in the medical field to appoint more male or physically fit female nurses to ICU rescue teams in hospitals so that the quality of CPR operations provided can be improved. Finally, it is recommended that if female nurses are to give compressions, they will be allowed to continue compressions just for 60-90 seconds, and then be replaced by another rescuer.

\section{Acknowledgements}

We would like to thank the Vice Chancellor for Research of Sabzevar University of Medical Sciences for supporting this research financially. We also gratefully acknowledge the cooperation of nursing personnel who work in Sabzevar hospitals, Khorasan Razavi, Iran. 


\section{References}

1. Salari A, Mohammadnejad E, Vanaki Z, Ahmadi F. Survival rate and outcomes of cardiopulmonary resuscitation. Iran J Critical Care Nurs 2010;3(2):45-9.

2. Berg RA, Hemphill R, Abella BS, Aufderheide TP, Cave DM, Hazinski MF, et al. Part 5: Adult basic life support 2010 American Heart Association guidelines for cardiopulmonary resuscitation and emergency cardiovascular care. Circulation 2010;122(18 suppl 3):S685-S705. https://doi.org/10.1161/CIRCULATIONAHA.110. $\underline{970939}$

3. Hasegawa T, Daikoku R, Saito S, Saito Y. Relationship between weight of rescuer and quality of chest compression during cardiopulmonary resuscitation. J PhysiolAnthropol 2014; 24;33:16. doi: 10.1186/1880-6805-33-16. https://doi.org/10.1186/1880-6805-33-16

4. Williams B, Boyle M, Gutwirth H. Rescuer Fatigue in Cardiopulmonary Resuscitation: A Review of the Literature. Australas JParamed 2012;7(4):4.

5. Abella BS, Alvarado JP, Myklebust H, Edelson DP, Barry A, O'Hearn N, et al. Quality of cardiopulmonary resuscitation during inhospital cardiac arrest. Jama 2005;293(3):305-10. https://doi.org/10.1001/jama.293.3.305

6. Heidenreich JW, Berg RA, Higdon TA, Ewy GA, Kern KB, Sanders AB. Rescuer Fatigue: Standard versus Continuous Chest-Compression Cardiopulmonary Resuscitation. Academic emergency medicine 2006;13(10):1020-6. https://doi.org/10.1111/j.1553-2712.2006.tb00272.x
7. Williams B, Boyle M, Gutwirth H. Rescuer Fatigue in Cardiopulmonary Resuscitation: A Review of the Literature. Australas JParamed 2012;7(4):4.

8. Nasiripour A, MasoudiAsl I, Fathi E. The relationship of CPR success and time of patients' referring to emergency department. J Mil Med 2012;14(1):21-5.

9. Brimnejad L. Presence effect of professional resuscitate on cardiopulmonary resuscitation outcome in EmamKhomeyni hospital. J BabolUniv Med Sci 2009;10(3):55-61.

10. Bjørshol CA, Sunde K, Myklebust H, Assmus J, Søreide E. Decay in chest compression quality due to fatigue is rare during prolonged advanced life support in a manikin model. Scand J Trauma ResuscEmerg Med 2011;19(1):1-8. https://doi.org/10.1186/1757-7241-19-46

11. Riera SQ, González BS, Álvarez JT, FernándezMdMF, Saura JM. The physiological effect on rescuers of doing 2 min of uninterrupted chest compressions. Resuscitation 2007;74(1):10812.

https://doi.org/10.1016/j.resuscitation.2006.10.031

12. Ashton A, McCluskey A, Gwinnutt C, Keenan A. Effect of rescuer fatigue on performance of continuous external chest compressions over 3 min. Resuscitation 2002;55(2):151-5. https://doi.org/10.1016/S0300-9572(02)00168-5

13. Cassidy C. A Comparison of Fatigue during Cardiocerebral Resuscitation with Different Compression Rates Among Layperson and Professional Rescuers: California Polytechnic State University, San Luis Obispo; 2014.Available at: 
http://digitalcommons.calpoly.edu/cgi/viewconte nt.cgi ?article $=2399 \&$ context $=$ theses https://doi.org/10.15368/theses.2014.150

14. Darabi F, Amolaee K, Assarezadegan M, Seifi F, Razlansari H, Darestani K, Azizy F. Frequency of nursing and midwifery errors in referred cases to the Iranian Medical Council and Imam Reza Training Hospital in Kermanshah. J Kermanshah Univ Med Sci 2009;13(3).

15. Foo NP, Chang JH, Lin HJ, Guo HR. Rescuer fatigue and cardiopulmonary resuscitation positions: a randomized controlled crossover trial. Resuscitation 2010;81(5):579-84.

https://doi.org/10.1016/j.resuscitation.2010.02.006

16. Tseng BY, Gajewski BJ, Kluding PM. Reliability, responsiveness, and validity of the visual analog fatigue scale to measure exertion fatigue in people with chronic stroke: a preliminary study. Stroke research and treatment. 2010;2010.
17. Russo SG, Neumann P, Reinhardt S, et al. Impact of physical fitness and biometric data on the quality of external chest compression: a randomised, crossover trial. BMC emergency medicine 2011;11(1):20.

https://doi.org/10.1186/1471-227X-11-20

18. Krikscionaitiene A, Stasaitis K, Dambrauskiene $\mathrm{M}$, et al. Can lightweight rescuers adequately perform CPR according to 2010 resuscitation guideline requirements? J Emerg Med 2013;30(2):159-60.

https://doi.org/10.1136/emermed-2011-200634

19. Uhm DC, Jun MH, Hwang JY, Choi JY. Knowledge according to learning experiences of CPR for health occupation college students. J Korean AcadSocNursEduc 2008;14(1):138-46. https://doi.org/10.5977/JKASNE.2008.14.1.138

20. Khalifa GE, Alfonzo A, Arntz $H R$, et al. European Resuscitation Council Guidelines for Resuscitation 2015. Resuscitation 2015(95):1-80. 


\title{
Studija faktora koji se odnose na fizički umor nakon kardiopulmonalne resuscitacije i kvalitet resuscitacije
}

\author{
Mojtaba Rad, Mostafa Rad \\ ${ }^{1}$ Član fakulteta za sestrinstvo i akušerstvo, Univerzitet medicinskih nauka u Sabzevaru, Sabzevar, Iran \\ ${ }^{2}$ Fakultet za sestrinstvo i akušerstvo, Univerzitet medicinskih nauka u Sabzevaru, Sabzevar, Iran
}

\begin{abstract}
SAŽETAK
Efektivna kompresija grudnog koša je važan faktor koji ima ključnu ulogu kod preživljavnja bolesnika sa srčanim zastojem. Razumevanje faktora koji dovode do ranog fizičkog zamora može da pomogne u unapređenju kvaliteta kardiopulmonalne resuscitacije koja se izvodi u bolnicama. Stoga, cilj ove studije bio je procena faktora relevantnih za početak fizičkog umora i kvalitet resuscitacije za vreme kardiopulmonalne resuscitacije koju izvode medicinske sestre u Iranu.

Ova studija preseka je uključila 194 ispitanika iz različitih bolničkih odeljenja, izabranih metodom slučajnog uzorka. Od učesnika je traženo da izvedu kardiopulmonalnu resuscitaciju na lutki za reanimaciju. Dok su izvodili reanimaciju, vreme i kvalitet kompresija mereni su pomoću hronometra i vizuelno analogne skale za merenje umora. Učesnici su sami prijavljivali početak osećaja fizičkog umora.

Statistička analiza prikupljenih podataka je ukazala da je većina učesnika osetila izuzetno jak fizički umor nakon dvominutnog izvođenja kardiopulmonalne resuscitacije. Oko $71,2 \%$ učesnika je uspelo da izvede kompresiju dublju od $5 \mathrm{~cm}$. Fizički umor koji su učesnici osetili bio je u korelaciji sa težinom, polom, stepenom obrazovanja i radnim mestom učesnika $(p<0,05)$. $S$ obzirom da su rezultati studije pokazali da su različiti faktori, uključujući pol, težinu, visinu, stepen obrazovanja i radno mesto osobe koja izvodi reanimaciju bili u značajnoj korelaciji sa početkom osećaja fizičkog umora $u$ toku izvođenja reanimacije, preporuka je da muškarci sa većom težinom i visinom rade $u$ timovima spasioca na odeljenjima urgentne medicine. Štaviše, nameće se kao obaveza da medicinske sestre koje rade u ovim timovima poboljšaju svoju fizičku kondiciju kroz redovne vežbe aerobika, što bi ubuduće dovelo do manjeg zamaranja tokom izvođenja kardiopulmonalne resuscitacije.
\end{abstract}

Ključne reči: fizički umor, kardiopulmonalna resuscitacija, kvalitet, medicinske sestre, efikasnost 